\title{
Bilim ve Yaratıcı Drama Eşliğinde Doğa Eğitimi
}

\author{
Dr.Pınar Özdemir*, Bilm.Uzm. Nejat Akfırat**,Yrd.Doç.Dr.H.Ömer Adıgüzel*** \\ *Hacettepe Universitesi, **Milli Eğitim Bakanlığı, ***Ankara Üniversitesi
}

$\mathrm{Bu}$ çalışmanın amacı yaratıcı dramanın bir öğretim yöntemi olarak doğa eğitimi konusunda ilköğretim öğrencileri üzerindeki etkisini belirlemek ve çalışmaya dahil olan lider ve eğiticilerin görüşlerini ortaya çıkarmaktır. TUBITAK destekli olan "Bilim ve Yaratıcı Drama Eşliğinde Doğa Tarihinden Doğa Müzesine Yolculuk” isimli bu çalışma; 2008 yılında üç ayrı dönemde Ankara ili Kazan ilçesine bağlı Yazıbeyli mahallesinde 2005 yılında kurulan "Ütopya" adlı Oyun Bilim ve Sanat merkezinde uygulanmıştır. Bu çalışma çerçevesinde adı geçen merkez, eğitim mekânı olarak kullanılarak ilköğretim okullarının dört ve beşinci sınıflarından oluşan 30' ar kişilik üç grup halinde 90 öğrenci grubuna bölgenin sahip olduğu kayaç, fosil ve mineral zenginliğini tanıtarak, bölgenin son 35 milyon yıllık dönemine ilişkin jeolojik ve paleoantropolojik evrimi tanıtılmıştır. Eğitime ilişkin konular, kendi alanlarında uzman, popüler dili olan eğitmenler tarafından verilmiştir. Tüm bu süreç için kullanılacak temel yöntem yaratıcı dramadır. Çalışma çeşitli arazi gezileri ile desteklenmiştir. 8 haftada gerçekleştirilen toplam 48 saat süren çalışmanın sonunda öğrencilerle ve eğiticilerle yapılan görüşmeler ve sürecin gözlemlenmesi sonucunda elde edilen sonuçlara göre çalışmaya katılan öğrencilerin doğa eğitimi ile ilgili temel bilgi ve becerileri kazandığı söylenebilir. Ayrıca çalışmaya katılan eğiticiler ülkemizde bu tür çalışmaların sayısının arttırılması gerektiğini söylemişler ve çalışmaya katılan öğrencilerin araştırarak ve gözleme dayalı olarak öğrendikleri bilgilerin anlamlı öğrenme sağladığı ve kalıcı olduğunu vurgulamışlardır.

Anahtar Kelimeler: Yaratıcı drama, kayaç, fosil, değerli taş.

\section{Giriş}

Çocuk en erken yaşlardan başlayarak merak ettiği, görebildiği, dokunabildiği, duyabildiği, kısacası duyularını kullanabildiği, gözlemleyebildiği ve test edebildiği bir ortamda çok daha hızlı ve etkin bir öğrenme gerçekleştirilebilir. Bunu sağlayan ortamsa önceden yapılandırılmış etkinliklerin planlı bir şekilde sunulduğu sınıf ortamından çok, doğanın ta kendisidir. Doğal yaşam alanları, öğrenmenin en hızlı gerçekleştiği açık hava laboratuvarlarıdır. Doğal yaşama verilen zararlar, bunun neden ve sonuçları doğa eğitiminin çevre eğitimiyle kesiştiği önemli bir kavşak noktası olup, doğa eğitimi çocuklarımızın 
yaşadıkları ve gelecekte yaşayacakları çevre sorunları konusunda farkındalık oluşturmaları, bu sorunların çözümüne yönelik stratejiler geliştirmeleri, kişisel ve toplumsal ölçütte öncelik almaları için kendilerini geliştirmelerine yönelik olanaklar sunmaktadır.

Etkili ve kalıcı bir çevre eğitimi hedefleniyorsa, çocuğun yakın çevresinin ve bu çevredeki değişimlerin farkına varmasını sağlayacak temalar seçip belirli bir program dahilinde çeşitli etkinliklerle destekleyerek çocuğun ilgisini çevre üzerinde yoğunlaştırmak gerekir. Çevre bilincinin geliştirilebilmesi için eğitimcilerin çocuklara, çevreyle ilgili bilgi vermeleri, çevreyi benimsetmeleri, çevreyle ilgili yeterli materyal sağlamaları, özendirici eylemler geliştirmeleri ve uygulama sonuçlarını somutlaştırarak çevre ile ilgili değer ve yargılarını geri beslemeleri gerekmektedir Bunları sağlayabilmek için de karşımıza yaratıcı drama çıkmaktadır (Şimşekli, 2001).

Yaratıcı dramadaki öğrenme, bir tür yeniden yapılanmadır. Öğrencilerin, çocuk ya da genç, öğrendiklerini, bilgilerini yeni bir bakış açısından değerlendirmesidir. Kazanılmış kavramların irdelenmesi, bu kavramlara yeni anlamlar yüklenmesi söz konusudur. Deneyim ve yaşantılar yeniden gözden geçirilir. Tüm bu süreçler doğal bir öğrenmeyi getirir. Yaratıcı drama ile edinilen bilgilenme, okul disiplinleri içinde edinilen ezbere dayalı, kuramsal bilgilenme değildir. Yaratıcı dramada gene çeşitli disiplinlerden gelen bilgi kullanılır ama bu kez bilgiler ünik bir biçimde dünya ile kurulan öznel ve nesnel ilişsiler içinde yapılanır. Eğitim kurumları genellikle bu tür öğrenmeyi sağlayamamaktadırlar. Bunun için de yaratıcı dramanın eğitimde kullanımı bir gereksinmedir. Yaratıcı drama çalışmaları, demokratik, çeşitli ve değişik ilişkileri görebilen, bağımsız düşünebilen, hoşgörülü ve yaratıcı çocuk, ergen ve gençler yetiştirmeye yöneliktir ve hep biliyoruz ki günümüzün bilinçli gençliği yukarıdaki nitelikleri kazanmaya gerçekten isteklidir (Adıgüzel, 1994; San, 1989).

Türkiye'de yeni geliştirilen ve tüm okullarda uygulamaya konulan ilköğretim 4 . ve 5 . sınıflar Fen ve Teknoloji Dersi Öğretim Programında çevre konularına geniş yer verilmiştir. Ancak bu konuların ele alınışında, uygulama aşamasında halen geliştirilmeye açık alanların ve boşlukların bulunduğu görülmektedir. Bu boşluklardan bir tanesi, alan gezileri ve bu gezilerde gerçekleştirilecek uygulamalı etkinlikler de ortaya çıkmaktadır. Oysa alan gezileri aktif bir öğrenme ortamı oluşturarak öğrencinin aynı anda birçok yönden gelişimini hızlandırıcı olma özelliğine sahiptir. Yaratıcı drama bir konunun katılımcıların yaşantılarından yola çıkarak grup etkileşimi içinde işlenmesine çok uygun ve tamamen katılımcı odaklı bir yöntemdir. Dünya'da ve Türkiye'de yapılan bazı çalışmalar incelendiğinde yaratıcı dramanın çevre eğitiminde aktif olarak kullanılması gerekliliğini ortaya koymuştur. 
Teksas' taki Çevre Eğitimi Uygulamalarına İlişkin Gözlemler ABD'de 1956 yılında ilk taslağı hazırlanan "Doğal Yaşamı Koruma Yasası"nın 1964 yılında Johnson tarafından imzalanmasıyla doğal yaşam, bilimsel ve eğitimsel amaçlar için halka açılmıştır. Çevre eğitiminde milli parklar, göl, nehir kıyıları, sulak alanlar doğal eğitim ortamları olarak okullarda verilen teorik eğitimin laboratuvarları olma özelliği taşımakta ve buralarda çalışan görevliler birer eğitmen olarak, okullardaki öğretim planlarıyla eşgüdümlü bir şekilde öğrencilere çevre eğitimi vermektedirler. Formel eğitimde ana sınıflarından üniversitelere uzanan bir çizgide her yıl öğretim planında öngörülen çok disiplinli etkinlikler, milli parklar gibi doğal alanlarda gerçekleştirilmektedir. Örneğin Anahuac Milli Parkı'nda yapılan eğitim çalışmalarında ana sınıfı öğrencileri oyunlarla doğada renk ve şekillerin çeşitliliğini keşfetmektedirler.

Shangri La Botanik Bahçelerinde 4. sınıftan 5. sınıfa geçen öğrenciler yaz aylarında "Sulak Alanların Harika Dünyası" adı altında, 4 büyük sulak alanı çalıştıkları bir projeyi gerçekleştirilmekte ve çalışmanın sonunda Eco-Rangers unvanı almaktadırlar. Eğitim fakültesinden yeni mezun olmuş öğretmen adaylarıysa bu botanik bahçelerinde bir yıl boyunca staj yapmaktadırlar. Burada gökbilimden hayvanbilime uzanan bir çizgide eğitim çalışması öğretmenlere ücretsiz olarak verilmektedir (http://www.shangrilagardens.org/Programs/Educational-Programs.aspx, 21.10.2008). 2003 yazında Shangri La Botanik Bahçeleri ve Doğa Merkezinde öğretmenlere yönelik Doğa Eğitimi Yaz Enstitüsü Projesi başlatılmıştır. Bu tür doğal alanlar ayrıca formel olmayan eğitimde de geniş katılımlı olarak kullanılmakta ve gönüllü yetişkinlere doğa eğitimi verilerek daha sonra bu kişilerin öğrenci gruplarına eğitmen olarak hizmet vermelerine olanak sağlamaktadır. Üniversite, sivil toplum kuruluşları ve gönüllü katılımcıların işbirliği ile düzenlenen 'Dinozorlar Günü' etkinlik örneğinde olduğu gibi kumların arasına saklanan balina kemikleri, bitki ve hayvan fosilleri ilköğretim öğrencilerine oyunlar yoluyla buldurulmakta, böylelikle gün boyu süren etkinlikler sırasında bu fosillerin kaynakları, oluşumları ve çeşitli özellikleri uygulamalı olarak öğretilmektedir (www.ekoses.com, 21.10.2008).

Tokgöz’ün 2002 yılında Başkent Üniversitesi Ayşe Abla Fen Lisesinde yaptığı Geri kazanımın çevre eğitiminde ve çevre korumadaki yeri ve önemi konulu proje çalışmasının sonucu şu şekilde ortaya çıkmıştır: "Yapılan proje çalışmasının ana unsuru yaratıcı drama yöntemiyle geri kazanım konusuna düşünsel, duygusal ve bedensel boyutlarla yaklaşımlar ortaya çıkarmaktır. Çalışmayı yürütmede seçilen yöntem sayesinde öğrencilerin yaptıkları ile öğrenmesi, duyu organlarını harekete geçirmesi sağlanmıştır. En önemlisi belki kendilerinin de ifade ettiği gibi 'unutulmaz yaşantılar' elde etmeleridir. Yaratıcı Drama yöntemiyle 'Geri 
kazanım' konusuna duyarlılığın üretimle ifadesi üzerine uygulanan bu proje göstermiştir ki yaşamın her anında bir dönüşüm söz konusudur. Ancak ögrenmemiz gereken fark edilmeyi beklemeden doğal kaynaklarımızı düzenli, dengeli bir şekilde kullanmaktır”

Gökbulut'un 2002'de Gelincik anaokulunda okulöncesi çocuklarına yaratıcı drama yöntemiyle, çocukların yaşantılarından yola çıkarak yaşadığımız çevreye duyarlılık kazandırmak, çevre bilinci oluşturmak ve bu bilinci toplumun değişik katmanlarına yaygınlaştırmak amacıyla yapılan projenin sonucunda katılımcılardan gelen dönütlerde belirlenen hedeflere büyük ölçüde ulaşıldığı düşünülmektedir.

\section{Çalışmanın Önemi}

İlköğretim 4. ve 5. sınıf Fen ve Teknoloji ders kitaplarında işlenen konulara paralel olarak kendi çevrelerinde bulunan zenginliklerden faydalanarak öğrendikleri bilgilerin kalıcı olması amaçlanmaktadır. Yaşadıkları çevrenin farkına varmaları ve yaşadıkları bölgenin ne kadar değerli olduğunu kavrayıp korumalarını sağlamak ve çevre bilincini aşılamaktır. Aynı zamanda doğa eğitiminin çocuklar için ne kadar önemli olduğunu göstermek ve doğa bilincinin küçük yaşlarda bireye edindirilebileceğidir.

\section{Çalışmanın Amacı:}

Kazan ve çevresinin sahip olduğu kayaç, fosil ve mineral zenginliği tanıtma ve bu bölgenin son 35 milyon yıllık dönemine ilişkin jeolojik ve paleoantropolojik evriminin tanıtılması amaçlanmaktadır. Bütün bu evrelerin yaratıcı drama kullanılarak içselleştirilmesi hedeflenmektedir.

\section{Yöntem}

Örneklem: Kazan ilçesinde bulunan ilköğretim okullarının dört ve beşinci sınıflarına devam eden ve gönüllülük esasına göre seçilen 30'ar kişiden üç grup halinde toplam 90 öğrencinin toplam 48 saatte Kazan İlçesi ve çevresindeki Tarihi değerleri hakkında bilgi edinmeleri; kayaçların, denizel ve karasal fosillerin ayırdına varabilmeleri için uzman kişilerden bilgi edinmeleri ve bu bilgileri drama yöntemiyle pekiştirmeleri amaçlanmıştır.

Çalışmaya Kazan İlçesinde bulunan Hamdiye Ünlü İlköğretim Okulu, Tahsin Şahinkaya İlköğretim Okulu, Şahin İlköğretim Okulu ve İbrahim Bitik İlköğretim Okulu katılmıştır.

Çalışmanın Yaklaşım, Yöntem ve Teknikleri: Yaratıcı Drama temel yöntem olarak kullanılmıştır. Bunun yanında soru-cevap, düz anlatım, gezi-gözlem, araştırma, yorumlama, sınıflandırma gibi tekniklere de yer verilmiştir. Çalışmada uygulanan plan örneklerinden biri Ek’te verilmiştir. 
Veri Toplama Aracı: Öğrenciler her günün sonunda gün içinde neler yaşadıklarını anlatan mektuplar yazmışladır. Çalışmalar sürecinde de gün içinde çeşitli değerlendirme etkinliklerine yer verilmiştir.

Bulgular ve Yorumlar: Çalışmada görev almış bazı eğitmenlerin süreç ile ilgili görüşleri aşağıdaki gibidir:

“Öğrenciler fosilleşmiş olan objelerin ağaç olduğunu gözleriyle görmüşler, o objelerin güncel çam, ardıç ağaçları gibi kökleri, gövdelerinin, budaklarının, dallarının ve yaşam halkalarının olduğunu görmüşler, hatta fosilleşmiş ağaç tohumu, pelitçik bulmuşlardır. Saha gezisinin hemen ardından, sahadan ayrlmadan çocuklar izlenimlerini, gördüklerini ve öğrendiklerini drama eşliğinde canlandırmışlar ve bu yöntemle doğayı tanımaları, onların dağarcıklarında yer etmesi daha kolay olmuştur."

"Araziden toplanan örneklerin daha yakından incelenmesi ve fosillerin isimlerini öğrenme aşaması olarak gerçekleştirilmiştir. Bir çeşit uygulama yapma çalışmasıdır. Önce yere bir yaygı serilmiş ve daha sonra, tüm fosiller bu yaygının üzerine konulmuştur. Tüm çocuklar yaygının etrafina oturmuşlar ve diledikleri fosili ellerine alıp, neye benzediklerini anlamaya çalışmışlar ve fosillerin isimlerini öğrenmişlerdir. Bu çalışma sırasında, yazı tahtasına basit şematik çizimler yapılmış ve öğrencilerden bunları defterlerine çizmeleri ve yanlarına da isimlerini yazmaları istenmiştir. Daha sonra her öğrenci eline aldiğg fosilin ismini inceleyerek kendi başına adlandırabilmiştir."

"Süreçte dersin öncesinde ve sonrasında yapılan drama çalışmaları; çocukların dikkatini toplamaya, derse istekli olmaya, kendilerine güvenlerini sağlamaya yaradiğını gözlemledim. Güvenç Köyüne denizel fosil sahasına gidildiğinde, çocukların merak ve istekle fosil toplamaları, topladı̆̆ fosillerle ilgili sorular sormaları, havanın güneşli ve sıcak olmasına răgmen heyecanla katılımları, yöntemin doğruluğu hakkında ipucu verdi. Yani okullarımızda kapalı sınıflarda verilen eğitimin, konunun uygunluğuna göre dış mekanlarda uygulanması gerektiği, çocukların yaparak yaşayarak öğrenmelerinin daha keyif vereceğ kanisina vardim."

$\mathrm{Bu}$ sonuçlardan eğitmenlerin yaratıcı drama yöntemi ile işlenen dersten oldukça keyif aldıkları, öğretirken öğrendikleri ve çocuklar için de öğrenilen bilginin anlamlı olmasını düşündükleri sonucuna varılabilinir. Doğa eğitimlerinin önemi ve bu eğitimi verirken yaratıcı drama yönteminin etkisi eğitmenlerin üzerinde durduğu en önemli konudur.

Katılımcıların çalışma boyunca yazdıkları mektuplardan bazı alıntılar aşağıdaki gibidir: 
"Burada oynadığımız oyunlar ve yaptı̆̆ımız çalışmalar hem bilim hem de eğlence içeren etkinlikler. Ben bu bir hafta içinde çok eğlendim ve birçok yeni bilgi edindim."

"Işslediğimiz konular ile ilgili bir konuyu grupça dramatize ettik. Kampın en sevdiğim kısmı buydu. Çünkü eğlenirken bilgilerimiz pekiştiriyorduk. Hocalarımız bizlere çok güzel oyunlar oynattı. ... Bu bir hafta içerisinde senin de benim yanımda olmanı çok isterdim. Birlikte ĕglenir, birlikte ögrrenirdik.”

“ilk gün hiç kimseyi tanımıyordum. Oyunlar oynadık ve birbirimizi tanıdık.”

"Burada hem oyun oynuyor, hem de ders işliyoruz."

\section{Sonuç ve Öneriler:}

Öğrencilerin süreç içinde yapmış oldukları etkinliklerde alan uzmanlarından öğrendikleri bilgileri canlandırmaları ile bilgileri içselleştirdikleri süreç sonunda yapılan sunumlarda görülmüştür.

Anlamlı öğrenme ve bilgide kalıcılık sağlanması hedeflerinden oldukça uzak bir eğitim sistemi içerisinde bu tür projeler öğrencilere doğa eğitiminin verilmesi yanında birçok kazanımı içermektedir. Özellikle ilköğretim çağındaki öğrenciler için fen ve doğa eğitimi, fen bilgilerinin aktarılmasından çok, çocuğun merakını giderecek yönde olmalıdır. Verilen eğitimlerde ilgi ve merak uyandırmak kullanılan öğretim yöntemi ile yakından ilgilidir. Ayrıca eğitimlerde bir öğretim yöntemi olarak kullanılan yaratıcı dramanın da öğrencilerin kişisel gelişimleri, yaratıcılıkları, sosyalleşmesi ve kendini ifade etmeyi sağlaması gibi birçok konuda fayda sağladığı düşünülürse, bu tür projelerin sayılarının artması gerektiği düşünülmektedir.

\section{Kaynakça}

Adıgüzel, Ö. (1994). Eğitimde yeni bir yöntem ve disiplin: Yaratıcı drama. Ö. Adıgüzel, (Ed.), Yaratıcı drama içinde (158-179). Ankara: Naturel Yayıncılık.

Gökbulut, Ö. Ö. (2002). Yaşadığımız Çevreye Duyarlılık Konusunun Okulöncesi Çağındaki Çocuklarla Yaratıcı Drama Yöntemiyle İşlenmesi, avaliable online. http://www.yaraticidrama.org/index.php?option=com_content\&task=view\&id=102\&Itemid= $55,30.03 .2008)$.

San, İ. (1989). Eğitimde yaratıcı drama. Ö. Adıgüzel, (Ed.), Yaratıcı drama içinde (5768). Ankara: Naturel Yayıncilik.

Şimşekli, Y. (2001). Bursa' da Uygulamalı Çevre Eğitimi Projesine Seçilen Okullarda Yapılan Etkinliklerin Okul Yöneticisi ve Görevli Öğretmenlerin Katkısı Yönünden Değerlendirilmesi”, Bursa: Uludağ Üniversitesi Eğitim Fakültesi Dergisi, Cilt: XIV, Sayı:1 
Tokgöz N. 2002. available on line. Geri kazanım ve Drama, http://www.yaraticidrama.org/index.php.option=com_content\&task=view\&id=96\&Itemid=55 , 30.03.2008).

\section{EK}

1. GÜN

\section{OTURUM - SABAH*}

Tarih: 05.04.2008 - 16.06.2008-11.10.2008

Mekan: Ütopya Oyun Bilim Sanat Merkezi

Konu: Tanıma - Tanışma, İletişim - Etkileşim, Temel Bilime Giriş.

Katılımcılar: Kazan İlçe Milli Eğitim Müdürlüğü, İlköğretim Okul Müdürlükleri ve Okul Rehber Öğretmenleri ile işbirliğinde seçilecek 30 ilköğretim 4 ve 5. sınıfa devam eden öğrenciler

Süre: 3 saat $(09.30-12.30)$

Araç ve Gereçler: Mekanda saklanmak üzere değişik kartpostallar, minderler.

Yöntemler: Yaratıcı Drama

Teknikler: Doğaçlama, rol oynama, (oyun)

Etkinlik 1: Katılımcılar çember olurlar. Katılımcı kendi adını ve adının baş harfiyle başlayan nesne, hayvan, vb adını söyleyerek ona uygun bir devinimde bulunur (Özge öykü gibiyim, Ferhat fırtına gibiyim vb.). Bu tüm grup tarafından tekrarlanır. Yanındaki katılımcıda aynı şekilde oyuna devam eder (Yanındakine El Çırparak Ad Söyleme: Katılımcılar çember olurlar. Lider sağındaki ya da solundaki katılımcıya el çırpıp kendi adını söyler. Katılımcı da ya aynı yöne ya da ters yönde el çırpıp kendi adını söyler. Katılımcı en fazla üç kez yön değiştirebilir. Tüm katılımcılar ismini en az bir kere söyleyene kadar oyun devam eder. Oyunun ikinci aşamasında ise katılımcı kendi ismini söylemek yerine yönünü döndüğü kişinin adını el çırparak söyler. Bu çalışmaya alternatif olarak sunula bilir).

\section{* Bütün çalışmalar kamera ile kayda alınarak ve fotoğrafları çekilerek belgelendirilmiştir.}

Etkinlik 2: Lider sağından ya da solundan herhangi bir nesneyi yanındaki katılımcının adını söyleyerek verir. Nesne sağa veya sola isimler söylenerek elden ele aktarılır. Lider ilerleyen zamanda nesne sayısını gruba göre arttırır. Nesneler fazlalaştığında bir kişide birden 
fazla nesne olmayacaktır. Nesneler katılımcının elinde 5 saniyeden fazla kalmayacaktır. Çember sürekli değişir (Topla Tanışma: Katılımcılar çember olurlar. Elinde top olan katılımcı diğer katılımcılardan herhangi birine kendi adını söyleyerek topu atar. Topu alan kişi aynı şekilde başka bir katılımcıya kendi adını söyleyerek topu atar. Bu oyun herkes en az bir kez adını söyleyene kadar devam eder. Oyunun ikinci aşamasında top atılırken katılımcı kendi adını söylemek yerine top attığı kişinin adı söyler. Bu çalışmaya alternatif olarak sunula bilir).

Etkinlik 3: Mekanı Tanıma: Mekana önceden 6 çift nesne farklı yerlere saklanır. Katılımcılara mekanda 6 çift nesnenin olduğu söylenir (nesnelerin ne olduğu söylenmemelidir). $\mathrm{Bu}$ nesnelerden çift bularak getirenlere ödül verileceği ancak bir nesne bulduklarında eşini bulmadıkları sürece nesneyi alamayacakları belirtilir.

Etkinlik 4: Meyve Sepeti: Katılımcılar çember olurlar. Katılımcıların sırasıyla toprak, değerli taş, kayaç, fosil adlarını almaları sağlanır. Ortaya bir tane gönüllü seçilir. Ortadaki katılımcı hangi ismi söylerse o kişiler yerlerini değiștirirler. Ortadaki de kendine bir yer bulmaya çalışır. Ortada kalan katılımcı ebe olur ve o da belirlenen isimlerden birini söyleyerek kendine yer bulmaya çalışır. Ortadaki ebe yerbilimi derse çemberdeki herkes yer değiştirir.

Etkinlik 5: Yuvanı Bul: Katılımcılar ikili eş olurlar. Eşler kol kola girerler. İki kişi ortaya geçer. Biri kaçan diğeri kovalayandır. Kaçan ebelenmemek için eşlerden birinin koluna girer. Girdiği kolun diğer tarafındaki katılımcı kaçan durumuna girer. Kovalayan kaçanı yakalarsa, kendisi kaçan olur. Ev Sahibi - Kiracı: Katılımcılar üçer kişilik gruplar oluşturur. Her gruptan iki kişi el ele tutuşur, üçüncü kişi ise bu kişilerin ortasına geçer. Ortada bir tane ebe vardır. Lider 'değişin' dediğinde kenardaki eşler ellerini açar ve ortadakiler kendilerine yeni ikili grup içinde yer bulurlar. Ebe de bu sırada kendine ikili gruplardan birinde yer bulur. Ortada kalan kişi ebedir. Oyun bu şekilde devam eder. Bu çalışmaya alternatif olarak sunula bilir).

Etkinlik 6: Katılımcılardan grupta en az görüştükleri kişiler ile ikili grup olmaları istenir. Eşlerden kendilerini A ve B olarak belirlemeleri sağlanır (Her bir doğaçlama 6' şar adet çoğaltılır). 
1) A: Siz bir öğrencisiniz. Arazide dolaşırken değerli bir taş buluyorsunuz. Önce siz gördüğünüzü düşünüyorsunuz. Taşı tam alacağınız sırada bir arkadaşınız geliyor, önce kendisinin gördüğünü düşünüyor ve taşı o almak istiyor.

B: Siz bir öğrencisiniz. Arazide dolaşırken değerli bir taş buluyorsunuz. Önce siz gördüğünüzü düşünüyorsunuz. Taşı tam alacağınız sırada bir arkadaşınız geliyor, önce kendisinin gördüğünü düşünüyor ve taşı o almak istiyor.

2) A: Öğretmeniniz sınıfa geldi ve bir projede çalışacak gönüllü bir öğrenciye ihtiyacı olduğunu söyledi. Siz bu projede yer almak istiyorsunuz. Bir arkadaşınızda aynı şekilde projede yer almak istiyor. Arkadaşınızı projeye katılmamaya ikna ediniz.

B: Öğretmeniniz sınıfa geldi ve bir projede çalışacak gönüllü bir öğrenciye ihtiyacı olduğunu söyledi. Siz bu projede yer almak istiyorsunuz. Bir arkadaşınızda aynı şekilde projede yer almak istiyor. Arkadaşınızı projeye katılmamaya ikna edin.

3) A: Okulda bilim kulübüne başkan olmak istiyorsunuz. Bu görevi en iyi kendinizin yapacağını düşünüyorsunuz. Diğer başkan adayını kendinizin bu görevde daha faydalı olacağınıza ikna edin.

B: Okulda bilim kulübüne başkan olmak istiyorsunuz. Bu görevi en iyi kendinizin yapacağını düşünüyorsunuz. Diğer başkan adayını kendinizin bu görevde daha faydalı olacağınıza ikna edin.

4) A: Okuldaki öğrenciler ile birlikte bir geziye gittiniz. Arazide bir arkadaşınızın ender bulunan bir fosile zarar verdiğini görüyorsunuz. Arkadaşınıza bunu yapmaması gerektiğini açıklayın.

B: Okuldaki öğrenciler ile birlikte bir geziye gittiniz. Arazide bulunan bir fosili incelemek için elinize aldınız. Bu fosilin çok önemli olduğunu düşünmüyorsunuz.

5) A: Siz bir bilim adamısınız. Bu bölgede eski tarih dönemlerini içeren fosil alanları bulunmaktadır. Gerekli araştırmaları ve incelemeleri yapmak istiyorsunuz.

B: Bir işadamısınız. Bu bölgede bir fabrika yapmak ve bir an önce fabrikayı faaliyete geçirmek istiyorsunuz. Bölgenin fosil yatağı olduğunu biliyorsunuz ama fabrikanın ülkeye daha fazla katkı geçirecek olduğunu düşünüyorsunuz. 
A' lara ve B' lere durumlar verildikten sonra doğaçlamalara başlanır. Bir süre sonra lider eşlerden rol değiştirmeleri sağlanır ve bir süre sonra doğaçlamalarını kesmelerini ister. Doğaçlamalar sırayla katılımcılar önünde tekrarlanır. Lider, doğaçlama sırasında başka bir ikiliden doğaçlamaya kaldığı yerden devam etmesini ister.

Değerlendirme:

Etkinlik 7: Katılımcıların önlerine kraft kağıtları koyulur. Bugünkü çalışmada neler hissettiklerine dair kağıtlara birer cümle yazmaları sağlanır. 